\section{The Right to Unionize, the Right to Bargain, and the Right to Democratic Policing}

\author{
By \\ MONIQUE MARKS \\ and
}

JENNY FLEMING
This (normative) article explores the importance of police unions in the quest for democratic policing. The authors argue that if we are to expect police to behave democratically, it is important for police themselves to experience democratic engagement within the organizations in which they work. That is, if police are expected to defend democracy, they should not be denied basic democratic rights such as the right to collective bargaining and the right to freedom of association. The authors contend that police unions, through networking with other social justice groupings and through encouraging democratic practice, constitute a real forum for the promotion of democratic policing. For this potential to be reached, however, police unions need to identify with broader labor movement trends toward community unionism.

Keywords: police labor rights; community unionism; democratic policing

$\mathrm{T}$ his article explores the importance of police unions in the quest for democratic policing. We argue that if we are to expect police to behave

Monique Marks is a research fellow at the Regulatory Institutions Network (RegNet) at the Australian National University. Prior to joining RegNet, she was a senior lecturer in the Sociology Department at the University of KwaZulu Natal in South Africa. Her research interests include police reform, police labor relations, youth politics, and ethnographic encounters. Her recently published book is Transforming the Robocops: Changing Police in South Africa (2005).

Jenny Fleming is a fellow at the Regulatory Institutions Network (RegNet) in the Research School of Social Sciences at the Australian National University in Canberra, Australia. She is a former research fellow with the Key Centre for Ethics, Law, Justice and Governance at Griffith University, Brisbane, Australia, from which she holds a doctorate. She is the coeditor with I. Holland of Motivating Ministers to Morality (2001, Ashgate) and Government Reformed: Values and New Political Institutions (2003, Ashgate) and publishes widely on police management, police unionism, and criminal justice administration. Her research interests include police labor relations, police-government relations, and the politics of criminal justice.

NOTE: The authors would like to acknowledge the support of the Australian Research Council for parts of this article (Grant nos. LP0346987 and LP0348682).

DOI: $10.1177 / 0002716206287181$ 
democratically, it is important for police themselves to experience democratic engagement within the organizations in which they work. In the literature, democratic policing is often discussed with reference to accountability structures and processes, civilianization, policing outcomes and performance measurement, and community participation and partnerships. However, there is almost no mention of the labor and social rights of police employees.

\section{[I]f we are to expect police to behave democratically, it is important for police themselves to experience democratic engagement within the organizations in which they work.}

We argue that if police are expected to defend democracy, they should not be denied basic democratic rights such as the right to collective bargaining and the right to freedom of association. Through being part of collective representative organizations, police may begin to appreciate the significance of freedom of association. Through engaging in collective bargaining processes, police may acknowledge the rights of social groupings to engage in collective action. Yet despite the link between organizational police democracy (the democratic internal workings of these organizations) and societal democracy (where citizens are able to participate in decision-making processes and where basic human rights are protected), the social and labor rights of the police are often constrained by regional, national, and international regulatory frameworks.

Like other trade unions, police unions can be narrowly self-interested, focusing their energies on workplace improvement and status enhancement. Unions also have the tendency, as Robert Michels cautioned almost a century ago, to become highly bureaucratized, resulting in rank-and-file union members "inevitably be[ing] controlled by a tiny minority . . . [and] thwart[ing] democratic aspirations within trade union structures" (Burgmann and Burgmann 1998, 63). These tendencies may seriously inhibit the democratic potential of the trade union movement but should not be cause for pessimism. As Alvin Gouldner has observed (cited in Burgmann and Burgmann 1998, 63), an "iron law of democracy" operates as effectively as Michels's "iron law of oligarchy." As Burgmann and Burgmann noted,

Trade unions are among the most democratic organisations in our society, certainly more democratic in general than corporations, parliamentary parties and governments. $(1998,63)$ 
Indeed, trade unions (including police unions) have, over time and across continents, demonstrated a real concern with democratic rights and with social justice agendas.

\section{Through being part of collective representative organizations, police may begin to appreciate the significance of freedom of association.}

In a number of instances, unions are "broadcasting agendas for social change" and aligning themselves with social movements for racial justice, gender equality, and urban change (Johnston 2000, 139-40; Robinson 2000). In many cases, these unions are building on hitherto obscured but "strong histor[ies] of democratic and militant unionism and intelligent and progressive union leadership" (Wooding, Levenstein, and Rosenberg 1997, 126). A case in point is the Police and Prisons Civil Rights Union (POPCRU) in South Africa. Based on this case as well as data about police unions in Europe and in America, we contend that police unions potentially constitute a real vehicle for the promotion of democratic policing. For this potential to be reached, however, police unions need to identify with broader labor movement trends toward community unionism. This form of unionism promotes strong alliances with social justice groupings as a means for building union profiles and influence and for achieving positive public interest agendas (Tattersall 2004). This networking may also play a role in preventing police unions from oligarchical tendencies because leaders will have to look outward in setting their agendas and in doing so call upon the active support of their members.

This article takes a normative approach. It incorporates existing knowledge about police unions while constructing future paths that we believe police unions could and should take. Normative judgments tell us what ought to be the case (Mayhew 2000). These judgments are generally based on hypothetical directives, using empirical data, where possible, to "throw a flood of light on the discovery of norms and obligations" (Walhout 1957, 48). The premise of the normative approach taken in this article is as follows: democracy is built through active participation of citizens in decisions that affect their lives and through "opposition to entrenched patterns of unjustified inequality” (Sklanksy 2005b, 1808). Police officers are most likely to cherish the rules and ideals of democracy if the organization in which they work promotes internal political participation at both the individual and collective level and if police representative organizations engage with social justice issues. 


\section{Global Trends in Trade Unionism}

Trade unions can be thought of as, to borrow a term from Tom Nairn (1997), "Janus-faced" organizations. They have the potential both to advance social justice agendas and to be narrowly concerned with their own vested interests (Hyman 2000; Prasad and Snell 2004). In recent decades, trade unions have displayed their vested interest face more often than they have revealed their social justice features (Levi 2003; Hyman 2000). Bureaucratic conservatism has shaped much of the direction taken by the trade union movement in recent years.

The challenge for the trade union movement in the twenty-first century is for unions to overcome this conservatism and to reinvigorate and "redefine their role as a sword of justice" (Hyman 2000, 1). Change is necessary for two reasons. First, engaging in more social justice issues provides unions with an opportunity for much needed revival. Second, through being involved in social justice issues, trade unions will increase their capacity to mobilize a broad range of civil society actors in pursuit of their public interest agendas. Some scholars suggest that the trade union movement offers a social democratic alternative to global neoliberalism (Lambert 2000; Adler and Webster 2000). But to be able to achieve these objectives, trade unions must

be part of a major social movement in which organised labour plays a crucial role while acting as a reciprocal participant in a larger network of social activists. An increasing number of unions - although still too few-are democratising internally, engaging in issues of economic and social justice for others as well as themselves. (Levi 2003, 60)

How unions identify themselves, what agendas they decide to promote, and whom they forge alliances with are all contingent on a number of factors. These include the political opportunity structure at the local, national, and global level; the characteristics of union members and supporters; the extent to which unions are viewed as valuable within networks of influence; the vision of union leaders; and, importantly for this article, the frameworks of international regulatory organizations such as the International Labor Organization (ILO).

Trade unions have been central to democratic transitions in the Pacific region, Asia, and Southern Africa. In these regions, trade unions were forced to respond to multiple challenges resulting from interlinked economic and political crises. Political instability compelled trade unions to "focus their attention on broader issues related to democracy and human rights" (Prasad and Snel 2004, 268; see also von Holdt 2002; Lambert 2000; Muhsin 2005).

Trade unions are not only important proponents of social justice in regions of the world struggling to create democratic institutions and practices. Even in established democracies, trade unions retain a democratic impetus (for example, see Burgmann and Burgmann 1998). Waterman (2004) suggested that

while examples of autocratically run and bureaucratic trade unions, some well known, exist in many countries, it remains true, nonetheless, that the trade union movement as a whole is by far and away the most democratic institution in every society and certainly the only major democratic international movement worldwide. (p. 5) 
Waterman also acknowledged the oligarchical tendencies within trade unions. However, he maintained that the large membership base of trade unions (from subordinated groupings) and the geographic reach they have provide them with the potential to deepen and broaden support for democratic principles. Trade unions are, moreover, often the only mass democratic organizations in a given society capable of organizing large numbers of citizen groupings across the boundaries of nation-states.

Trade union scholars are beginning to consider ways that trade unions can break out of their bureaucratic conservatism to implement new programs within a broad social justice framework through (re)engaging more strategically and ideologically with community-based groupings. Unionists and scholars refer to "community unionism" (Wills 2001; Tattersall 2004) to denote a form of trade unionism where unions develop new models of organizing through reaching out to groups with interests beyond the workplace. Johnston $(2000,140)$, writing of trade unions in the United States, talked about trade unions as moving toward "social movement unionism" where the unions are prepared to build new alliances and employ more confrontational tactics in promoting gender justice, immigrant rights, and urban social change. These trade unions are trying new strategies, building new coalitions, and rethinking their agendas. They are also mobilizing and representing "working people beyond the boundaries of the bargaining unit, in dealings not limited to employers and on issues not limited to the scope of recognition" (p. 142).

Governments are also starting to take stock of the important role that trade unions can play in governance networks. For example, in South Africa, the National Economic Development and Labour Council (NEDLAC) was established by the democratic government in 1995, ushering in a new era of inclusive decision making and consensus seeking in the economic arena. NEDLAC represents four constituencies-organized labor, government, business, and the community. Its aim is to prevent unilateral decision making. The social partners in NEDLAC have key roles to play in developing effective policies to promote urgently needed economic growth, increased participation in economic decision making, and social equity on a sustained basis (see http://www.nedlac.org.za/).

In Britain, following the election of the New Labour government in 1997, "trade unions have become increasingly important agents in local and regional development and governance" (Pike, O'Brien, and Tomaney 2004, 103). Trade unions are now viewed as important stakeholders, shaping legislation and creating opportunities for trade unions to engage directly in local and regional development issues, to expand their own agendas beyond the shop floor, to build alliances with other local and regional organizations, and to challenge traditional ways of organizing.

\section{The Spirit of Police Unions}

Police unions, much like other unions, can be both conservative and forward looking in their outlook. They have also, over time, demonstrated real oligarchic tendencies as their agendas have become increasingly conservative and as leaders have become entrenched within individual police unions. ${ }^{1}$ Perhaps more than any 
other union, police unions attract much controversy and evoke strong reactions from academics, police managers, and the public. Goldstein (1979) best summarized the divergent responses to police unions:

Some see the [police] unions as the natural enemies of change; as committed to protecting the hard earned gains reflected in the status quo. Others see the unions as a new and potentially dynamic force for positive change, especially as they press for more democratic police organisations. (p. 312)

Police managers and supervisors view police unions as disruptive entities within highly disciplined organizations (Halpern 1974). Policing scholars condemn them as obdurate organizations (Fogelson 1977; O'Malley 2005). Politicians regard them anxiously as powerful interest groupings able to (improperly) influence public perceptions and voting patterns (Kadleck 2003; Barker and Carter 1994; Finnane 2002). Even those who ideologically support the police union movement as an avenue for worker participation within the police organization "object to the often conservative content of their policy proposals" (Reiner 1978, 151). Police unions, like other trade unions, have taken on the character of "business unionism" (Voss and Sherman 2000) where union representatives spend most of their time promoting members' welfare and routinely supporting them in disciplinary hearings or in legal matters (Fleming and Marks 2004; Swanton 1982).

Some, however, recognize police unions as important social agencies with the capacity to positively influence policing trends (Sklansky 2005a; O’Malley 2005; Fleming, Marks, and Wood 2006). Police stakeholder groups in Canada have come to realize that "if police mangers foster respectful and collaborative relations with police unions/associations, there will be less likelihood of labor conflict and less reason for the association/union to take extraordinary measures to present their issues" (Biro et al. 2000, 15). They recognize that police associations/unions may provide police managers with the only forum by which to communicate with police members and as a vehicle for gaining support for change processes. Police unions, in their view, can provide platforms for the formulation of policies oriented to greater professionalism and to improving partnerships with communities and other stakeholders. In addition, their involvement in decision-making processes within police organizations has led to a weakening of "management rights, powers and traditional autocratic authority" (Hewitt 1978, 218), thereby creating more participatory and democratic processes within police organizations (Fleming and Marks 2004).

The democratic challenge that police unions present within police organizations was recognized in the early 1970s by William Ker Muir. Muir (1977), through his study of Oakland police, discovered that police are more likely to have a capacity for tolerance and an affinity for deliberation and compromise if their workplaces embrace these values internally. For the most part, though, the democratic impetus of police unions is seldom recognized in the literature, and yet a number of police unions have taken the lead in promoting more just, equitable, and effective policing.

Perhaps the best example of such a police union is POPCRU in South Africa. POPCRU was formed in 1989 during a period of defiance on the part of the mass democratic movement against apartheid. POPCRU has consistently pushed management for more transparent and even-handed policing. POPCRU was launched 
when a group of black police officers in the Eastern Cape province came together in defiance of brutal apartheid policing (Hopkins 2004). While POPCRU does practice business unionism, it has maintained a democratic policing agenda. At its 2004 General Conference, a number of key resolutions were articulated that reflect POPCRU's concern with both the internal democratization of the South African Police Service and with the furtherance of democratic policing within communities. In that forum, POPCRU resolved to allocate resources to speed up the transformation in the criminal justice system, to advance the equitable redistribution of police resources, to embark on a campaign to eradicate police corruption, to push for the targeting of women for leadership positions within the Police Service, to challenge the unilateral behavior of police employers and managers, and to campaign to narrow the wage gap between high-ranking and rank-and-file police (POPCRU 2004).

In 1997, POPCRU affiliated to the progressive trade union federation in South Africa and has since engaged in campaigns aimed at "defending the interests of communities against unpopular socio-economic policies" (Marks and Fleming 2004). POPCRU's commitment to democratic governance has been recognized by international human rights organizations. In August 2004, Shizue Tomoda, one of the ILO's technical specialists, wrote a letter to POPCRU's president:

I am confident that under your leadership POPCRU will grow further and will be an important instrument in the promotion of truly democratic labour relations not only in South Africa but also in the neighbouring countries in the region and eventually the entire continent. POPCRU's commitment to the principle of good governance and quality service delivery is a model for any public service anywhere in the world. Viva POPCRU!

POPCRU is not the only police union pursuing democratic governance agendas. The European Confederation of Police (EUROCOP) is an association of police unions across Europe. It has twenty-seven member organizations. Since January 2004 EUROCOP has been a participant in the Council of Europe. Through this participation, EUROCOP is able to directly approach government delegations to the Council of Europe. EUROCOP has a number of missions related to the development of European policing and is committed to "the promotion of fairness and equal opportunities in the police service, its own bodies and its member organizations" (EUROCOP 2004, 3).

EUROCOP has supported police officers throughout Europe who wish to unionize. In February 2005, EUROCOP held a conference devoted to the policing of a unified Europe. The conference looked at the constructive role that police unions could play in the planning of reform and transition processes within the police (see http://www.eurocop-police.org/events/eurocop/20050228-riga/20050228-riga.htm).

EUROCOP, representing unionized police officers in Europe, has charted a democratic policing pathway. While EUROCOP was established in 2002, it draws on a long history of democratic police unionism in Europe. As Berkley (1969, 46-51) reminded us, as early as the 1960s, "highly developed" police unions in France, Sweden, Germany, and the United Kingdom were demonstrating a progressive outlook. Berkley provided several examples of how police unionism facilitated the creation of the "democratic policeman." 
In Australia, too, police unions have shaped the reform agenda in very direct ways and initiated a number of important reviews of police organizations (Fleming and Marks 2004). These reviews have largely centered on resourcing and working conditions. However, some of the police unions have taken up broader reform agendas.

The New South Wales Police Association's involvement in the Royal Wood Commission (established in 1994 to examine the existence or otherwise of entrenched police corruption in the New South Wales Police [Wood 1997]) and the subsequent reform agenda, for example, have been much remarked on. It made extensive submissions supporting radical change, including integrity testing and greater external oversight (Fleming and Lewis 2002, 92). The Northern Territory Police Association (NTPA) also played a central role in exposing that territory's resource problem, particularly within remote Aboriginal areas. The territory's government publicly lauded its contribution. The NTPA went further to advocate mechanisms for equalizing the treatment of Aboriginal Community Policing Officers (Fleming, Marks, and Wood forthcoming).

At the local level, evidence indicates that police union members are reported to have closer links with community groupings than those police who are not unionized. Magenau and Hunt (1996) argued that police unionization in the United States "has increased the political power of the rank and file, relative to other network partners." While they criticized police unions' law enforcement agendas, their data confirm that union officers have better police-community relations than nonunionized police. This finding, they said, is consistent with other work on public sector unions that indicates that these unions identify with and promote public interest agendas. Rank-and-file behavior is then more consistent with community preferences. This public interest agenda is also evident in the demands of police union members for governments to release the findings of public reports, even when these may reflect poorly on the police organization (Portland Press Herald 2005).

\section{Police Unions, Collective Bargaining, and Democratic Policing}

In a recent handbook for assessing police performance in democratizing countries, Bruce and Neild (2005) insisted that police themselves must be treated as citizens if we are to expect them to behave democratically toward other citizens. They effectively draw the link between the internal democratization of police organizations and the external democratization of police conduct. According to them, "the fact that police are citizens, means they are entitled to the rights, privileges and benefits of citizenship" (p. 41). They argued that central to recognizing the police as citizens is their right to decent conditions of service, the right to form employee representative organizations, and the right to engage in collective bargaining (p. 43).

As early as 1947, an Australian historian and civil libertarian, Brian Fitzpatrick, made a similar point. Fitzpatrick asserted that if police had full political rights-including the right to unionize- "it would be harder for them to be used in the service of political repression." Fitzpatrick defended the rights of police to unionize as "consistent with the advancement of democracy and good governance" (see Finnane 2002, 131-32). 
For Fitzpatrick, democratic police reform and more participatory police management practices are synonymous. Berkley (1969) concurred with Fitzpatrick:

The trade union tends to make the policeman think of himself [sic] as a trade unionist, and thereby to identify with what is usually a pro-democratic, and somewhat left of center sector of democratic society. This is important, since policemen often experience a pull to the right. . . . Thus, the trade union can act as a countervailing force which keeps the police in the mainstream of democratic society. (pp. 46-47)

In the past three decades, attempts have been made to shift toward more corporate and participatory management styles coinciding with "the emerging consensus around a service-based, consumerist-approach to policing” (Reiner 1992, 267). Police managers have come to recognize the value of rank-and-file participation. They now view police members as entrepreneurs rather than employees (O’Malley 2005). Through more participatory management practices, police managers and supervisors are now required to promote, rather than restrict, creativity and problem-solving approaches (Birzer 1996). The technologies (problem solving, negotiation, consultation, partnership building) are also seen as crucial to community policing agendas that have been adopted by the police across the world. Participatory management is aimed at direct forms of participation by individual police. ${ }^{3}$

While community-oriented policing may call for more participatory styles of management, there are also intraorganizational rationales for introducing such management practices, especially during periods of organizational change. Like any work-based organization, it is crucial to bring all members of the police organization on board in times of transition. Change must make sense to those on the front line. If this does not occur, rank-and-file police officers are likely to feel threatened by change (Goldstein 1990; Van Heerden 1982; Washo 1984; Sykes 1986; Cowper 2004; Marks 2005).

Participatory management practices are not the only innovation required in police organizations for police to be responsive, creative, and collaborative. The right to more indirect forms of participation is just as important if police are to feel that they can effectively engage in codetermination processes. It is through collective representation that police officers (like other employees) are empowered to influence and shape decision-making processes within police organizations_-something that is extremely difficult to achieve as individuals given the hierarchical nature of police organizations. It is through participating via collective representative organizations (like trade unions) that individual members are afforded the opportunity to be informed and heard, to be involved in codetermination processes, and to negotiate important decisions that affect them individually and collectively (Peccei and Guest 2002).

The right of police officers to engage in direct and indirect forms of participation is crucial to rights-based awareness on the part of the police. Police are more likely to respond toward the public in democratic and fair ways if they themselves experience the benefits of democratic labor and social rights in their own organizational lives (Berkley 1969, 46-47). Put slightly differently, for police cultural knowledge about rights to be transformed and then reinforced, police themselves must be able to directly experience the benefits of newly awarded citizen rights so that shifts in cultural knowledge can occur. 
Rights awareness is not the only democratic benefit of police unionization. Police unions can play a number of other positive roles to advance democratic policing. Police unions can "serve as a necessary internal check against bureaucratic usurpation" (Gammage and Sacks 1972, 102). Through their engagement, police unions pose a challenge to the culture, decision-making processes, and traditionally austere atmosphere of public police agencies (Guyot 1979; Burpo 1971). Through collective bargaining activity, police unions serve to restrict the unilateral decision making on the part of police management (Levi 1978).

The unions should not be viewed as a thorn in the side of police managers or employers. Through (direct and indirect) participatory labor processes, employees are more likely to feel they have a positive stake in the policies, outcomes, and strategies of the organization (O'Brien 1994; Berkley 1969, 46). For these reasons O’Malley $(2005,8)$ has suggested that "police unionism should perhaps be moved to the forefront of our analysis of contemporary transformations in policing."

\section{Regulating Police Labor Rights-National and International Legislative Frameworks}

\section{Nation-states}

The legislative frameworks of sovereign nations largely determine the right of the police to unionize and to bargain collectively. These national frameworks are themselves dependent on a number of national dynamics including broad labor law legislation (at all levels of government), party political standpoints, social movement environments, and the configuration of police organizations. Police unions are most likely to be present in countries where

- freedom of association and collective bargaining rights are recognized,

- liberal or progressive political ideologies dominate,

- social movement organizations operate freely and civic engagement is encouraged, and

- hierarchical bureaucratic traditions within police organizations are challenged.

Where collective bargaining and freedom of association is proscribed, governments (and police management) argue that access to such rights will negatively affect the operational efficiency of the police. In these countries, government and police managers maintain that awarding police the rights to collective bargaining and freedom of association will diminish discipline and emasculate the chain of command (see below).

Police are denied the right to unionize and to bargain collectively in most African and Asian countries, many South American countries, and many Eastern European countries. The countries in which police are denied basic labor rights are usually emerging democracies, countries characterized as "weak states," or countries with authoritarian governmental approaches. In recent years, police who have been denied the right to unionize and to bargain collectively have made attempts to challenge national prescriptions. In so doing, they have turned to police unions in nearby countries for assistance. Police in Lesotho, Zambia, and Botswana, for example, have 
called upon the South African police union, POPCRU, to assist them in convincing police authorities and managers about the benefits of police unionization (see Hopkins 2004). The Papua New Guinea Police Association has called upon the Police Federation of Australia to assist with capacity building and entrenching the rights of the police in that country. Other organized forums of police officers have looked toward international labor regulatory bodies, such as the ILO, for assistance.

\section{The ILO}

The ILO is a key international body and a specialized agency of the United Nations responsible for promoting international efforts to improve working conditions, living standards, and equitable treatment of workers. One of the primary goals of the ILO is to formulate international labor standards in the form of conventions. A convention defines standards and provides a model for nations to follow. The ILO provides best practice benchmarks and aspirational norms.

It is a common belief that the ILO has no legal authority to enforce its recommendations on governments that are found to have violated basic ILO conventions. That belief is not entirely correct. An article in the ILO constitution permits the organization to take whatever action it deems necessary to bring about compliance with its core standards. ${ }^{4}$ However, it is a strong ILO custom to use moral suasion and the threat of weaker nations earning the disfavor of strong nations such as the United States or the European Union to persuade a government to reconsider its actions that are contradictory to basic international standards (Adams 2006).

The central role of the ILO, then, is to bring pressure to bear on countries that do not comply with internationally accepted core labor standards (Biffl and Isaac 2002). The ILO is therefore a key player in the "webs of influence" (Braithwaite and Drahos 2000) in the sphere of labor-management relations and employee rights. In the absence of an international authority like the ILO prepared to enforce specific labor standards, countries are free to pursue their own particular legislation and practices that may fall outside of international conventions.

In its official documentation, the ILO states that freedom of association and the right to collective bargaining are basic employment rights and are crucial to building democracy in any given country (ILO 2004). However, those police groupings that have turned to the ILO for assistance in acquiring these rights have been disappointed. Police groups from Argentina who have been mobilizing for labor rights are a good example of this.

In late 2003, two organized groupings of police members in Buenos Aires (Argentina) approached the ILO Body on Freedom of Association to review a decision by the Argentine government denying police members the right to unionize. ${ }^{5}$ The case emerged following attempts by the low-ranking Buenos Aires' police officers to form and register a police union (Obeid and Weisenberg 2003). These police officers argued that a police union would "not only improve police working conditions, but would also help curb the 'police mafia' and 'trigger happy' officers who are responsible for hundreds of deaths each year" (see Latinamericapress.org, http://www.communitiesbychoice.org/printme.cfm?ID=1226\&print=1). The Buenos Aires police hierarchy responded by opposing unionization and expelling "agitators" 
from the police. Similar responses occurred in other provinces of Argentina. Police authorities argued that police union activities "seriously affected discipline and responsibility for assignment of duties" (ILO 2003b, 4).

The government of Argentina, in making its case for the prohibition of police unions, made reference to the ILO's core labor conventions. It argued that its decision was in accordance with ILO Convention No. 87, which deals with freedom of association, and Convention No. 98, which deals with the right to collective bargaining. Argentina is a member state of the ILO and has ratified both Convention No. 87 and Convention No. 98. The Argentine government argued in its defense that these two conventions stipulate that relevant labor rights are not immediately applicable to the security forces. Instead, they pointed out, the ILO stipulates that national legislative frameworks should determine these labor rights, allowing for restrictions in the interests of national security or public order.

The Argentine government's reference to the ILO conventions was accurate. Conventions $87,98,151$, and 154 do not automatically apply to the police and the military. ${ }^{6}$ Unsurprisingly, then, when the case was referred to the ILO, the Committee on Freedom of Association concluded in favor of the Argentine government (ILO 2003b, 6).

The determination by the ILO, and the fact that it buttressed the limitations stipulated by the Argentine government, is significant for two reasons. In the first instance, the exclusionary clauses, as they currently stand, lump together the police and the military. In so doing, they reinforce characterizations of police organizations as militarized and as operating primarily with state interests in mind. This is problematic given that global trends in policing indicate that for police to operate in ways that are democratic and community oriented, clear distinctions need to be made between the functions and identity of the police and the military (Waddington 1999; della Porta and Reiter 1998).

Second, in deferring authority to national states in regard to police labor rights, the ILO is inadvertently safeguarding the agendas of governments characterized by autocratic rule, corrupt practices, and low levels of civic engagement. The market economy and domestic political maneuvers have not facilitated improved police employee rights, particularly in places like Africa and Latin America. Indeed, relying on the quality of domestic institutions and policies may seriously curtail what police may view as their "citizen" rights, in turn, negatively affecting the capacity of police members to contribute to the democratization of policing.

While an international network of police unions is attempting to persuade the ILO to review its conventions as they pertain to police, such changes are unlikely in the near future. The ILO is not an independent entity. It is the collective sum of all the member states, which includes representatives from trade unions, employers, and government. Inherent within this body are all the shortcomings and inefficiencies found in such bodies - many of which are opposed to police unionization. As Shizue Tomoda of the ILO points out,

As long as a large number of member states feel that it is proper for police labour rights to be regulated by national laws, the ILO Secretariat can do little to change the status quo. ${ }^{7}$ 
The ILO does revise its conventions from time to time. However, this only takes place when member states are ready for such revisions, which is not the case at present in regard to extending police labor rights. In the absence of such revisions, the ILO develops codes of practice. Such codes of practice promote, for example, social dialogue within the public service, including the public emergency services. In January 2003, the ILO held a Joint Meeting on Public Emergency Services and the meeting (which included police labor and management representatives) adopted a document titled "Guidelines on Social Dialogue for Public Emergency Services in a Changing Environment” in which fundamental labor rights such as freedom of association and the right to bargain collectively are promoted. While not legally binding, these guidelines do indicate a real attempt on the part of the ILO to engender a labor rights framework within this occupational sector (ILO 2003a).

A change in the ILO conventions would arguably provide a more robust reference point for those who promote police labor rights. But even if the ILO were to amend its conventions, the regulatory capacity of the organization is limited (Elliot 2000). The ILO can only resort to dialogue, moral suasion, and technical assistance in enforcing labor standards and conventions. In addition, most ILO members have not ratified most standards, leading many commentators to suggest that "the minimum standards were often set too high by the original members of the Western European club" (Braithwaite and Drahos 2000, 234). Many countries in the world still fail to comply with the basic conventions on freedom of association and the right to collective bargaining. Yet the ILO conventions are used to justify exclusions from certain rights - a target for "blame diversion," as we saw in the Argentine case.

As an international organization, the ILO has significant influence in regard to facilitating normative orders and practices for workplaces in both the private and public sector. Developing countries and countries whose governments prefer "union-free" environments ${ }^{8}$ may lack the institutional arrangements (and willingness) to develop and apply core labor standards on their own (Biffl and Isaac 2002). The ILO remains an important reference point for national governments in devising regulatory systems for police labor rights.

\section{Police Unions, the Labor Movement, and Community Unionism}

Even if regulatory frameworks facilitated police unionization, there is no guarantee that police unions would not succumb to the iron law of oligarchy-pursuing narrow conservative agendas and rejecting forward-thinking participative leadership. Much depends on whether these unions are willing to pursue the new trends within the trade union movement. This, to some extent, depends on whether police unions in the first instance identify with the broader trade union movement.

In many ways, police unions are best identified as industry-based organizations or trade unions, viewing their key role as representing the workplace interests of their members. They engage in collective bargaining and are prepared to employ 
confrontational tactics when consultative processes fail (Finnane 2002; Fleming and Lafferty 2001). But the question remains, Are police like other workers? The answer to this would be both yes and no. On one hand, as Reiner $(1978,151)$ put it, "Their condition and experience may incline them toward unionism." Indeed, police organizations have a comparative advantage with regard to police union potential. While technology has supplemented and continues to supplement some fields of policing, policing remains a labor-intensive industry. Where police unions do exist, they represent almost 100 percent of the members of the police organizationa real achievement given the decline of trade union membership internationally (Fleming and Peetz 2005; Finnane 2002; Farber 2005; Marks 2000).

On the other hand, police identities are profoundly shaped and reproduced through public symbols and icons that represent the constabulary as "central to the production and reproduction of order and security" (Loader 1997, 3) and the reproduction of dominant interests (Hall et al. 1978). There is, therefore, a tension between the police identifying with the broader labor movement and their being required to function as "reproducers of order" (Ericson 1982; Fleming and Marks 2004).

\section{Reciprocal relations between the labor movement and police unions may require police unions to adopt a stronger union- community approach in the future.}

The extent to which police unions identify and align themselves with the trade union movement is contingent on historical trajectories of the trade union movement, police union leadership, police subcultures, labor law legislation, police labor regulations, and the types of networks that police unions are part of. Interviews with police union officials in Australia revealed a deep ambivalence in identifying with the labor movement. This ambivalence was derived from a preoccupation with police professionalism and a conviction on the part of police union leaders that their social base is extremely conservative. Their preoccupation with organizational maintenance has resulted in a reluctance to generate internal discord by aligning with more far-reaching agendas than those that directly pertain to police workplace conditions (Fleming and Marks 2004).

The Police Federation of Australia has a formalized affiliation with the national trade union federation. But many police unions view the premise of this relationship as strategic rather than ideological. While an alliance with the labor movement is seen 
as strategically advantageous, this does not dramatically shape the self-identity of the police unions and their members. Australian police unions clearly indicated that they were unlikely to take up a range of the issues on the agenda of the broader labor movement, like, for example, gay rights issues or antiwar campaigns (Fleming and Marks 2004).

The ambivalence of Australian police union leaders is also evident in Canada. According to David Griffin, chief executive officer of the Canadian Professional Police Association, ${ }^{9}$ in the provinces of Nova Scotia, New Brunswick, and Saskatchewan, the police associations see themselves as unions and are part of the larger public sector union body. In Ontario (where police associations are prohibited from affiliating with any trade union) however, municipal police associations view themselves largely as professional bodies and tend not to align themselves with the interests of organized labor. ${ }^{10}$

\section{Strategically, then, police unions would be well advised to take stock of new trends in the union movement.}

Police unions in some countries do align themselves with the broader trade union movement. In South Africa, as mentioned earlier, POPCRU is an affiliate of the national trade union federation (Marks 2000, 2005). One of the resolutions taken by POPCRU at its 2004 national congress was "to constantly struggle to assert a working class and pro-poor perspective within the alliance" (POPCRU 2004, 16). In Brazil, the police union has on occasion publicly demonstrated solidarity with the labor movement. In 1997, the union joined forces with the Landless Workers' Movement and the Workers' Council in a campaign in protest of the government's neoliberal policies (Weekly News Update on the Americas 1997).

It is difficult to generalize about police union identities and strategic alliances. But what can be said with certainty is that police are as concerned about working conditions and wages as any other employees (Reiner 1978, 5). Even if not for ideological reasons, police unions are likely to look toward the labor movement as a source of support for their campaigns and as a source of inspiration for their tactics. Strategically, then, police unions would be well advised to take stock of new trends in the union movement. Reciprocal relations between the labor movement and police unions may require police unions to adopt a stronger union-community approach in the future.

The current global socioeconomic climate may compel police unions to associate more closely with other public sector unions. Public sector unions the world 
over are on the defensive with neoliberal governance and the entrenching of the regulatory state (Braithwaite and Drahos 2000). The increasing pluralization of policing through privatization, civilianization, and responsibilization will lead to significant changes in public police organizations and may compromise police union membership rates. As police unions battle to assert (and protect) the primacy of the public police in the policing industry, they may well cast an eye to other public sector unions for solutions to these new governance arrangements.

Should they choose this path, the new discourse that police unions are likely to share with other public sector unions in their fight against new governance arrangements would center on citizen rights to publicly accountable and professional service delivery. Police unions would then have to demonstrate that the services the public police provide are more accountable, more equitable, more democratic, and more professional than those of private police and civic police groupings.

The future challenge for police unions will be to find a balance between responding to traditional industrial concerns (which will always be a primary focus) and promoting democratic policing and social justice agendas. One way to do this would be to consider the route of community unionism. This will mean showing both faces of police unions - their vested interest face and their social justice face. David Griffin (2001) of the Canadian Professional Police Association has put this challenge:

In order for 21st century police associations or unions to be effective, they must engage in strategic activities which position the organisation as an influential and respected stakeholder on issues concerning the safe and effective delivery of police services to their communities. (p. 17)

The rights of the police as citizens to freely associate and to collectively bargain are likely to increasingly be intertwined with the rights of the broader citizenry.

\section{Conclusion}

In the ensuing years, the face of public police agencies will change dramatically. Contract employment and an emphasis on performance measurement will probably replace tenured employment. Civilians will continue to be employed in police organizations in nonoperational functions. Female and minority group representation is likely to increase within police organizations. Police are likely to be better educated and more aware of their individual rights and more concerned with issues of equal treatment and even affirmative action (Grabosky 2001; Griffin 2001). Consequently, they may become even more demanding of police employers with regard to working conditions, wages, benefits, and rights. The right to join police associations/unions and to engage in collective bargaining is likely to be viewed increasingly as a basic right of police members. However, the challenge for police unions is to align their rights with the democratic rights of 
those they police and to promote a police professionalism that is characterized by equitable, just, and effective service delivery.

\section{The ILO, as a key international regulatory body, would do well to take heed of the organizing capacity of this sector of workers as well as the potential democratic advantages that could flow from police labor rights.}

The past few decades have witnessed major reform movements within police organizations aimed at a more democratic police profession (Marenin 2004). However, both within academic and police discourse, democratic policing inevitably means "making the police answerable to democracy, not bringing the benefits of democracy to police officers themselves" (Sklansky 2005a, 1). Of course, this is not surprising given that where police have acted undemocratically, there are concerns that police should be reined in and made more accountable. We do not disagree with the need for police to be held accountable for their behavior both within police organizations and within the communities they serve. As we have suggested above, however, awarding police the rights of freedom of association and collective bargaining could facilitate the (further) democratization of policing. After all, in those jurisdictions where police have been allowed to organize and bargain collectively, civil disorder has not broken out. Through being able to freely form and join police labor organizations and engage in collective bargaining, police members are able to directly influence the governance of policing. Through collective bargaining processes, police are able to develop skills in problem solving and negotiation, both viewed as key to democratic policing. By being part of collective organizations, police members may begin to appreciate the importance of the right to freedom of association and freedom of expression generally, cornerstones of democratic societies.

Growing networks of police union representatives regionally and internationally will ensure that police unionization will continue to thrive. The ILO, as a key international regulatory body, would do well to take heed of the organizing capacity of this sector of workers as well as the potential democratic advantages that could flow from police labor rights. But change in conventions pertaining to police labor rights will only occur if member state constituencies agree to this. In this regard, member states of the ILO who maintain that police labor rights should be curtailed should be encouraged to reconsider these views. 
The limited capacity of the ILO to regulate police labor relations will mean that police employees and managers will need to turn to regional groupings and international networks of police representative organizations and advocates of police labor rights in developing fairer labor practices for police. In the short and medium term, the ILO could provide technical support to police who wish to form police unions and to engage in social dialogue with police managers and employers. This is already occurring to a limited extent in Southern and East Africa where the ILO is currently organizing technical workshops for the police focusing on labor law reform and collective bargaining skills. ${ }^{11}$

\section{If police unions are to positively contribute to the democratization of policing and to broader social justice programmers, they must not be pushed into the margins of scholarly works or left alone to fight for their existence in hostile national milieus.}

As we have pointed out, police labor organizations are not inherently progressive organizations, and they tend to focus on narrow vested interests. If they are to be taken seriously in police governance arrangements, they need to respond creatively to newly configuring social, political, and economic environments. If they are to be seen as legitimate organizations worthy of support from civic groupings and from government agencies, they will have to think seriously about their own definitions of professionalism and how they can contribute to the democratization of policing. Police unions will have to become, to borrow a term from Martin Godfrey (2003, 29), "swords of justice" rather than "protectors of vested interests." In so doing, they would need to consider aligning themselves with the broad labor movement, reaching out to community organizations, and expanding their agendas to include "issues of democracy, human rights and social justice not only in the context of labor relations but also in the larger society" (cited in Webster and Lambert 2003, 4).

As Tattersall (2004) has pointed out,

The process of reaching out is not only useful to maximise a union's capacity to achieve objective victories, but is also essential for unions to again be the central agents for improving the livelihood of working people, both inside and outside the workplace ... [such relationships] require a significant depth of commitment and participation by unions. (pp. 19, 2) 
Police unions are important stakeholders in the policing landscape, but they are not the only ones that need to demonstrate participation and commitment in building community relationships. If police unions are to positively contribute to the democratization of policing and to broader social justice programs, they must not be pushed into the margins of scholarly works or left alone to fight for their existence in hostile national milieus. The challenge, then, is not only directed at police unions but also at international regulatory organizations and scholars of the police to seriously engage with police unions so such organizations are able to contribute positively to debates on the future of policing and the realization of democratic citizen frameworks.

\section{Notes}

1. Less typically of oligarchic trade unions, police unions often resort to confrontational tactics in achieving their goals.

2. This letter was given to one of the authors by the general secretary of the Police and Prisons Civil Rights Union (POPCRU).

3. It is worth bearing in mind, as David Sklansky (2005a) rightly pointed out, that participatory management may be implemented as a means of thwarting policing unionism, not promoting it.

4. In fact, that provision has only been used once, against Burma for engaging in forced labor (personal communication, Roy Adams, December 2005).

5. For more detail on the Argentine story, see Marks and Fleming (forthcoming).

6. Article 9 (1) says, "The extent to which the guarantees provided for in this Covention (87) shall apply to the armed forces and the police shall be determined by national laws and regulations." In short, the International Labor Organization (ILO) does not say the provisions do not apply, rather that it is up to each state to decide the extent to which they do apply.

7. E-mail correspondence with Shizue Tomada, ILO Secretariat, March 19, 2004.

8. Adams (2001) argues the "union-free" philosophy is well and alive in North America. This school of thought proclaims that unions have no place in well-managed enterprises.

9. E-mail correspondence dated May 10, 2005.

10. E-mail correspondence with Dale Kinnear, Director of Labour Services, Canadian Professional Police Association, May 19, 2005.

11. E-mail correspondence with Jane Hodges, ILO labour law specialist, January 28, 2004.

\section{References}

Adams, Roy J. 2001. Human rights in employment: Implications of the international consensus for management teaching and practice. Journal of Comparative International Management 4 (1): 22-32.

- 2006. America's "union-free" movement in light of international human rights standards. In Justice on the job: Perspectives on the erosion of collective bargaining in the United States, ed. Richard Block, Sheldon Friedman, Michelle Kaminski, and Andy Levin. Kalamazoo, Michigan: W.E. Upjohn Institute for Employment Research.

Adler, Glenn, and Eddie Webster, eds. 2000. Trade unions and democratization in South Africa, 19851997. International Political Economy Series. New York: St. Martin's.

Barker, Thomas, and David L. Carter, eds. 1994. Police deviance. Cincinnati, OH: Anderson.

Berkley, George E. 1969. The democratic policeman. Boston: Beacon.

Biffl, Gudrun, and Joe Isaac. 2002. How effective are the ILO's labour standards under globalisation? Paper presented at the IIRA/CIRA 4th Regional Congress of the America's Centre for Industrial Relations, University of Toronto, June 25-29. 
Biro, Frederick, Peter Campbell, Paul McKenna, and Tonita Murray. 2000. Police executives under pressure: A study and discussion of the issues. Police Futures Group, Study Series no. 3. Ottawa, Ontario: Canadian Association of Chiefs of Police Publication.

Birzer, Michael L. 1996. Police supervisors in the 21st century. FBI Law Enforcement Bulletin 65 (6): 5-11. Braithwaite, John, and Peter Drahos. 2000. Global business regulation. Cambridge: Cambridge University Press.

Bruce, David, and Rachel Neild. 2005. The police that we want: A handbook for oversight of the police in South Africa. Resource Center Publications and Articles. http://www.soros.org/resources/articles_ publications/publications/police_20050125 (accessed November 15, 2005).

Burgmann, Meredith, and Verity Burgmann. 1998. Green bans, red union environmental activism and the New South Wales Builders Labourers' Federation. Sydney, Australia: University of New South Wales Press.

Burpo, John. 1971. The police labor movement: Problems and perspectives. Springfield, IL: Charles C Thomas.

Cowper, Thomas J. 2004. The myth of the military model of leadership in law enforcement. In Contemporary policing: Controversies, challenges and solutions, ed. Quint Thurman and Jihong Zhao. Los Angeles: Roxbury Publishing.

della Porta, Donatella, and Herbert Reiter. 1998. Policing protest: The control of mass demonstrations in Western democracies. Minneapolis: University of Minnesota Press.

Elliot, Kimberley A. 2000. The ILO and enforcement of core labour standards. International Economics Policy Briefs 6:1-7.

Ericson, Richard. 1982. Reproducing Order: A Study of Police Patrol Work, Toronto, Toronto University Press.

European Confederation of Police (EUROCOP). 2004. The voice of police news in Europe. March. http://www.eurocop-police.org/index.html (accessed November 4, 2005).

Farber, Henry S. 2005. Union membership in the United States: The divergence between the public and the private sectors. September. Working Paper no. 503, Industrial Relations Section, Princeton University, Princeton, NJ.

Finnane, Mark. 2002. When police unionise: The politics of law and order in Australia. Sydney, Australia: Institute of Criminology, University of Sydney.

Fleming, Jenny, and George Lafferty. 2001. Police unions, industrial strategies and political influence: Some recent history. International Journal of Employment Studies 9 (2): 131-40.

Fleming, Jenny, and Colleen Lewis. 2002. The politics of police reform. In Police reform: Building integrity, ed. Tim Prenzler and Janet Ransley, 83-96. Sydney, Australia: Federation Press.

Fleming, Jenny, and Monique Marks. 2004. Reformers or resisters: The state of police unionism in Australia. Employment Relations Record 4 (1): 1-14.

Fleming, Jenny, Monique Marks, and Jennifer Wood. 2006. Standing on the inside looking out: The significance of police unions in networks of police governance. Australian and New Zealand Journal of Criminology 39 (1).

Fleming, Jenny, and David Peetz. 2005. Essential service unionism and the new police industrial relations. Journal of Collective Negotiations 30 (4): 283-305.

Fogelson, Robert M. 1977. Big-city police. Cambridge, MA: Harvard University Press.

Gammage, Allen Z., and Stanley L. Sacks. 1972. Police unions. Springfield, MA: Charles C Thomas.

Godfrey, Martin. 2003. Employment dimensions of decent work: Trade-offs and complementarities. Discussion Paper DP/148/2003, International Institute for Labour Studies, Geneva, Switzerland.

Goldstein, Herman. 1979. Policing a free society. Cambridge, MA: Ballinger.

- 1990. Problem oriented policing, New York: McGraw-Hill.

Grabosky, Peter. 2001. Crime control in the 21st century. Australian and New Zealand Journal of Criminology 34 (3): 221-34.

Griffin, David. 2001. Police association advocacy-A strategic priority: Police associations, political activism and public opinion. Paper presented at the Police Employment in 2001 Conference, Toronto, Canada, February 27.

Guyot, Dorothy. 1979. Bending granite: Attempts to change the rank structure of american police departments. Journal of Police Science and Administration 7 (3): 253-84.

Hall, Stuart, Charles Critcher, Tony Jefferson, John Clarke, and Brian Roberts. 1978. Policing the crisis: "Mugging" the state and law and order. London: Macmillan.

Halpern, Stephen C. 1974. Police-association and department leaders: The politics of co-optation. Lexington, MA: D.C. Heath. 
Hewitt, William H. 1978. Current issues in police collective bargaining. In The future of policing, ed. Alvin W. Cohn, 207-23. Beverley Hills, CA: Sage.

Hopkins, Pat. 2004. Justice for all: The first 15 years of POPCRU. Cape Town, South Africa: Police and Prisons Civil Rights Union (POPCRU).

Hyman, Richard. 2000. An emerging agenda for trade unions? Labour Net Germany, http://www.labournet .de/index.html.

International Labor Organization (ILO). 2003a. Guidelines on social dialogue in public emergency services in a changing environment. Report from a joint meeting on public emergency in a changing environment, Geneva, Switzerland, January 27-31.

- 2003b. ILO governing body on freedom of association: 332nd Report of the Committee on Freedom of Association. November. Geneva, Switzerland: ILO.

- 2004. Organising for social justice. Report of the Director-General. International Labour Conference, 92nd Session, Report 1 (B), International Labour Office, Geneva, Switzerland.

Johnston, Paul. 2000. The resurgence of labor as citizenship movement in the new labor relations. Critical Sociology, 26 (1-2): 139-60.

Kadleck, Colleen. 2003. Police employee organisations. Policing: An International Journal of Police Strategies and Management 26 (2): 341-51.

Lambert, Rob. 2000. Trade unions, democracy and global change: South African Transitions. In A review of trade unions and democracy in South Africa, 1985-1997, ed. Glenn Adler and Eddie Webster. London: Macmillan.

Levi, Margaret. 1978. Conflict and collusion: Police collective bargaining. In Police accountability: Performance measures and unionism, ed. Richard C. Larson. Toronto, Canada: Lexington Books.

- 2003. Organizing power: The prospects for an American labor movement. http://depts.washington .edu/pcls/OrganizingPower.pdf (accessed February 1, 2006).

Loader, Ian. 1997. Policing and the social: Questions of symbolic power. British Journal of Sociology 48 (1): 1-18.

Magenau, John M., and Raymond G. Hunt. 1996. Police unions and the police role. Human Relations 42 (6): $547-60$.

Marenin, Otwin. 2004. Police training for democracy. Police Practice and Research 5 (2): 107-23.

Marks, Monique. 2000. Labour relations in the South African Police Service. In Public service labour relations in a democratic South Africa, ed. Glenn Adler. Johannesburg, South Africa: University of Witwatersrand Press.

- 2005. Transforming the robocops: Changing police in South Africa. Scottsville, South Africa: University of KwaZulu-Natal Press.

Marks, Monique, and Jenny Fleming. 2004. As unremarkable as the air they breathe? Reforming police management in South Africa. Current Sociology 52 (5): 783-807.

- Forthcoming. The untold story: the regulation of police labour rights and the quest for police democratisation. Police, Practice and Research.

Mayhew, David R. 2000. Political science and political philosophy: Ontological not normative. Political Science and Politics 22 (2): 192-93.

Muhsin, Abdullah. 2005. Iraqi labor unions and the war. April 27. http://politicalaffairs.net/article/articleview/ 1021/1/91/ (accessed November 15, 2005).

Muir, William K. 1977. Police: Street corner politicians. Chicago: University of Chicago Press.

Nairn, Tom. 1997. Faces of nationalism: Janus revisited. London: Verso.

Obeid, El Halli, and Laura L. B. Weisenberg. 2003. Case studies in social dialogue in the public emergency services-Argentina. ILO Sectoral Activities Programme Working Paper no. 193, Geneva, Switzerland, International Labor Organization.

O’Brien, Kevin M. 1994. Determinants of political activity by police unions. Journal of Collective Negotiations 23 (3): 265-78.

O'Malley, Pat. 2005. Converging corporatisation? Police management, police unionism, and the transfer of business principles. Paper presented the Centre for Market and Public Organisation, University of Bristol, UK, September.

Peccei, Ricardo, and David Guest. 2002. Trust, exchange and virtuous circles of cooperation: A theoretical and empirical analysis of operations at work. Research Paper 011, the Management Centre, Kings College, University of London. 
Pike, Andrew, Peter O'Brien, and John Tomaney. 2004. Trade unions in local and regional development and governance: The Northern Trades Union Congress in North East England. Local Economy 19:102-16.

Police and Prisons Civil Rights Union (POPCRU). 2004. Constitutional Amendments, Resolutions and Programme of Action, Book 4, 5th National Congress, June.

Portland Press Herald. 2005. Police unions serve public by demanding investigation's results. October 10 . http://pressherald.mainetoday.com/ (accessed November 15, 2005).

Prasad, Satendra, and Darryn Snell. 2004. The sword of justice: South Pacific trade unions and NGOs during a decade of lost development. Development in Practice 14:267-79.

Reiner, Robert. 1978. The blue coated worker: A sociological study of police unionism. London: Cambridge University Press.

- 1992. The politics of the police. London: Harvester Wheatsheaf.

Robinson, Ian. 2000. Neoliberal restructuring and US unions: Toward social movement unionism? Critical Sociology 26 (1-2): 107-37.

Sklansky, David L. 2005a. Democratic policing inside and out. Manuscript.

- 2005b. Police and democracy. Michigan Law Review 4:1699-1830.

Swanton, Bruce. 1982. Protecting the protectors. Canberra: Australian Institute of Criminology.

Sykes, Gary W. 1986. Automation, management and the police role: The new reformers? Journal of Police Science and Administration 14 (1): 24-30.

Tattersall, Amanda. 2004. Union-community coalitions and community unionism: Developing a framework for the role of union-community relationships in union renewal. Paper submitted to the International Colloquium on Union Renewal Conference HEC Montreal, Montreal, Quebec, Canada, November 18-20.

Van Heerden, T. J. 1982. Introduction to police science. Pretoria: University of South Africa Press.

von Holdt, Karl. 2002. Social movement unionism: The case of South Africa. Work, Employment and Society 16 (2): 283-304.

Voss, Kim, and Rachel Sherman. 2000. Breaking the iron law of oligarchy: Union revitalization in the American labor movement. American Journal of Sociology 106 (2): 303-49.

Waddington, Peter A. J. 1999. Police canteen (sub) culture. British Journal of Criminology 39:287-309.

Walhout, Donald. 1957. Is and ought. Journal of Philosophy 54 (2): 42-48.

Washo, B. 1984. Effecting planned change within a police organization. The Police Chief, November, pp. 33-35.

Waterman, Peter. 2004. Trade unions, NGOs and global social justice: Another tale to tell. Manuscript.

Webster, E., and R. Lambert. 2003. What is new in the new labour internationalism: A southern perspective. Paper presented at the seminar series in the Department of Sociology at the Rand Afrikaans University, Johannesburg, South Africa, March 7.

Weekly News Update on the Americas. 1997. "Open your eyes": Day of protest in Brazil. Issue 391, July 27.

Wills, J. 2001. Community unionism and trade union renewal in the UK: Moving beyond the fragments at last? Transactions of the Institute of British Geographers 26:465-83.

Wood, J. R. T. 1997. Royal Commission into the New South Wales Police Service, final report. Vols. 1-3. Sydney, Australia: New South Wales Police Integrity Commission.

Wooding, J., C. Levenstein, and B. Rosenberg. 1997. The Oil, Chemical and Atomic Workers International Union: Refining strategies for labor. International Journal of Health Services 27 (1): 125-38. 